\title{
Threats related to tourism and recreation in Natura 2000 areas, based on the analysis of the standard data forms (SDF) from the Alpine Bioregion of Slovakia
}

\author{
Szymon Ciapała, Paweł Adamski, Adam Mroczka, Juraj Svajda \& Zbigniew Witkowski
}

Keywords: Natura 2000 sites, Standard Data Form (SDF), impact of tourism, Slovak Alpine Region

\section{Abstract}

The aim of this study was to estimate the size and direction of tourism and recreation influence on protected areas within the Natura 2000 sites. The research covered sites in Slovakia within the Alpine Bioregion. Information included in the Standard Data Form (SDF) was analysed and the SDF used as a basic tool to collect data related to the Natura 2000 sites. The tool contains unified information of forms of activities within a given area, their intensity and effect (positive, neutral, or negative) on nature. The study revealed that almost a third of activities pursued in the Slovakian part of the Alpine Bioregion were related to tourism and recreation in the wider sense. Furthermore, the influence of the majority of activities on the environment was considered negative or neutral in all analysed Natura 2000 areas. Only ten forms of activities were found positive in some parts of the Natura 2000 sites. The findings also indicated that the intensity of the analysed activities was similar within the Natura 2000 sites and in the adjacent areas. However, the effects of the selected activities were more often found to be negative within the Natura 2000 sites than in their adjacent areas. The results obtained from this study suggest that broadly understood tourism and recreational activities can be considered an inherent element of human influence on biodiverse areas. They should be taken into consideration in managing and planning Natura 2000 sites and their adjacent areas.

\section{Introduction}

Tourism is often perceived as one of the most important elements of sustainable development (Kombol 2000; Krnacova et al. 2001). This form of activity combines the opportunities of economic development with the preservation of high environmental values of the area (Maikihuri et al. 2000; Neto 2003). At the same time, however, an excessive touristic load or its incorrect distribution in the region might result in the degradation of its environmental resources (Hresko \& Bugar 2001; Gorczyca \& Krzemien 2002).

The most remarkable examples of this phenomenon are the effects of the development of touristic infrastructure in the form of hostels, hotels, roads and railways, ski lifts and ski runs (Witkowski 1996; Lajczak 1996). The impact of tourism on the natural environment has recently been the subject of various (more or less comprehensive) studies (Lidl 1997). This interest stems from the mass character of tourism on the one hand (Freitag \& Pyka 2011), and the fact that attractive natural areas have also become popular destinations due to the growing interest in ecotourism, on the other (Reiter 2011). Therefore, among recreational areas, the protected areas, also included in the Natura 2000 ecological network, have begun to play a special role as well. These areas are monitored for the impact of various factors on the condition of the environment. On the basis of inventory studies, the person who submits the area to the Natura 2000 network is asked to fill in a Standard Data Form (SDF) on activities carried out in Natura 2000 areas as well as in the adjacent areas. The SDF has eight main sections, of which the sixth includes data on the possible threats or on activities with positive outcomes for the protected area.
The paper presents the results obtained from the analysis of the data in terms of their impact on the protected areas within the Natura 2000 network. The authors focused on activities related to tourism and recreation in the wider sense.

During the preparation of the Natura 2000 ecological network in Europe, the European Commission outlined the division of the territory into several biogeographic regions (Makomaska-Juchiewicz \& Tworek 2003; Dubiel et al. 2010; Wójcik 2010). Our study was limited to the areas of the Alpine Bioregion as defined by the EU nomenclature (ETC/BD 2006).

\section{Methods}

The paper is based on information included in the SDF for the sites established in the Slovakian part of the Carpathians (http://www.eea.europa.eu/dataand-maps/data/natura-2000). This source determines the accuracy and type of data presentation. The names and codes of activity types as well as categories of their intensity and effects were based on the EU instructions for the sites delimitation (Natura 2000 SDF Explanatory Note 1999).

The activities related to broadly understood tourism and recreation were selected from instructions in the SDF explanatory notes and further analyses carried out on these activities to establish whether their intensity and effects are similar in the Natura 2000 sites and in adjacent areas. The analyses were conducted by comparing the number of indicators within each intensity category and the direction of each selected activity. Frequency tests were applied to perform comparisons such as Pearson's Chi square, and Likelihood Ratio tests when data quantity did not meet test requirements (Sokal \& Rohlf 1995). 


\section{Results}

Based on the SDFs for all 285 sites in the Slovak part of the Alpine Bioregion, a total of 148 types of human activities with positive and / or negative effect on the Natura 2000 areas were identified in the Alpine Bioregion of a total number of 1397 number activities. Furthermore, $\mathbf{1 5 0}$ types of activities affecting the areas adjacent to the Natura 2000 sites were also de-

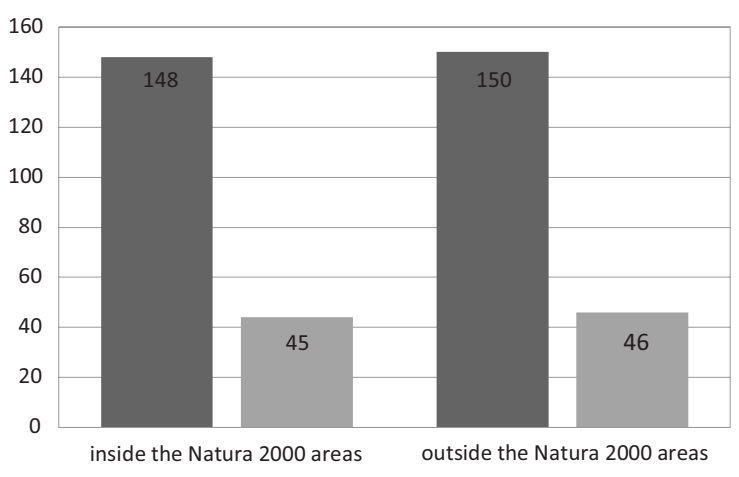

- all types of activities $\quad$ tourism and recreation-related activities

Figure 1 - The number of human activity types inside the Natura 2000 areas and in the adjacent areas (the Alpine Bioregion).

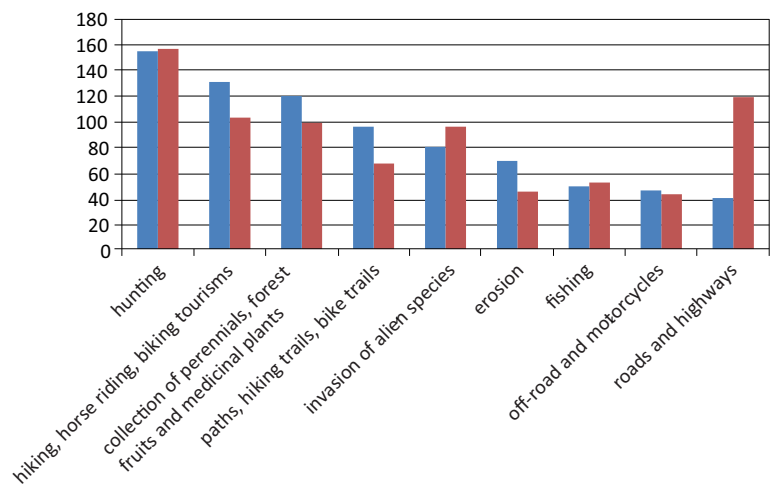

Figure 2 - The most frequent tourism-related activities reported from the 285 Natura 2000 areas as taking place inside the Natura 2000 sites (blue columns) and in the areas adjacent areas (red columns).

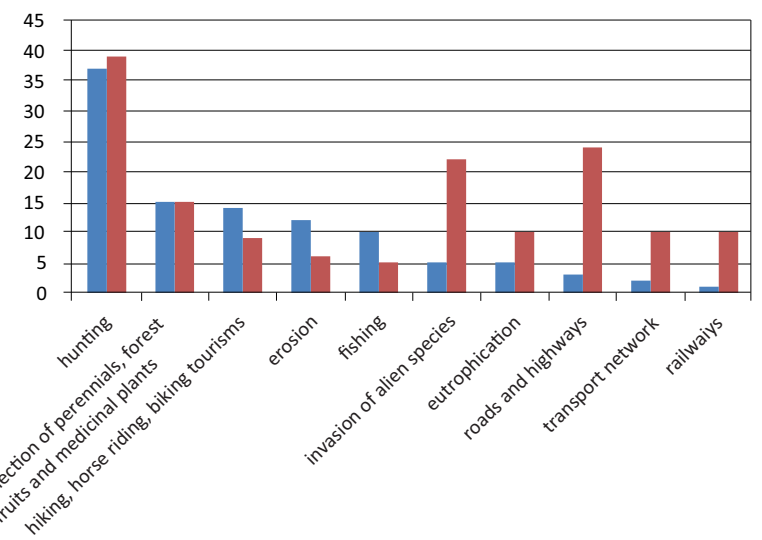

Figure 3 - The activities which most intensively affected the 285 Natura 2000 areas in the Alpine Bioregion (blue columns) and in the areas adjacent to the them (red columns). termined. However, only a few activities were tourism and recreation-related. After analysing the SDFs, the authors distinguished 45 types of activities inside the Natura 2000 areas and $\mathbf{4 6}$ types of activities in the adjacent areas (Figure 1).

The number and forms of tourism and recreation-related activities

Almost one third of all 150 types of activities carried out in the Alpine areas were associated with tourism. Not only the types of tourism-related activities were taken into consideration but also the activities which enable and facilitate the realization of touristic and recreational needs.

Table 1 shows the intensity of various types of tourism and recreation-related activities within the Natura 2000 areas in the Alpine Bioregion. The intensity of touristic and recreational activities and their effects were presented on a 3-point scale, in line with the SDF-adopted principles (Natura 2000 SDF Explanatory Note 1999).

Threats to the Natura 2000 environmental values may not only result from the tourism and recreationrelated activities pursued by people within the boundaries of a particular area, but also from activities carried out outside it in the adjacent areas. Table 2 shows the sources of such threats. However, in relation to the Table 1, a comparable variety of tourism and recreation-related activities which might pose a threat can be observed, and two other types of activities which do not take place inside the Natura 2000 area. These include position 16 (Airfields and helipads) and 23 (Stadiums) in Table 2. Given their rarity, these activities seem insignificant.

\section{Data analysis}

The analysis of the information obtained from the SDFs indicated that the particular threats associated with tourism and recreation in the majority of areas occur within their boundaries as well as in their adjacent areas.

The results obtained from the SDFs indicated that particular types of activities can vary in terms of the intensity of their impact on the area, see Figure 3.

The majority of human activities had a negative and only two (educational centres and tunnels) a positive effect, primarily on the areas in which they were located. Only 10 types of activities were considered positive in 28 cases of completed SDFs. They represent less than $2 \%$ of all (1397 cases) touristic and recreational activities in the Alpine Bioregion.

The analysis of the intensity of activities inside and in the vicinity of the Natura 2000 sites returned significant differences for only two types of activities: vandalism (code 740), with significantly higher intensity inside the site than in the vicinity $(\mathrm{p}=0,0125)$, and, in contrast, invasion of alien species (code 954), with significantly weaker or average intensity inside the site $(p=0,0062)$. 
Table 1 - Number of the Natura 2000 areas where tourism and recreation-related activities were recorded (the Alpine Bioregion). Source: authors' own studies

\begin{tabular}{|c|c|c|c|c|c|c|c|c|}
\hline \multirow[b]{2}{*}{ No. } & \multirow{2}{*}{$\begin{array}{l}\text { Activity } \\
\text { code }\end{array}$} & \multirow[b]{2}{*}{ Activity type } & \multicolumn{3}{|c|}{ Intensity of activity } & \multicolumn{3}{|c|}{ Effects of activity } \\
\hline & & & \begin{tabular}{|l|} 
strong \\
(A)
\end{tabular} & \begin{tabular}{|l|} 
average \\
(B)
\end{tabular} & $\begin{array}{l}\text { low } \\
\text { (C) } \\
\end{array}$ & $\begin{array}{l}\text { positive } \\
(+)\end{array}$ & $\begin{array}{l}\text { neutral } \\
(0)\end{array}$ & $\begin{array}{l}\text { negative } \\
(-)\end{array}$ \\
\hline 1 & 220 & Fishing & 10 & 21 & 18 & 2 & 27 & 20 \\
\hline 2 & 230 & Hunting & 37 & 76 & 42 & 2 & 104 & 49 \\
\hline 3 & 240 & Taking and removal of animals in general & 3 & 4 & 7 & 3 & 5 & 6 \\
\hline 4 & 241 & $\begin{array}{l}\text { Taking and removal insects, amphibians, or } \\
\text { reptiles }\end{array}$ & 2 & 7 & 26 & 0 & 4 & 31 \\
\hline 5 & 250 & Plant collection in general & 1 & 10 & 3 & 0 & 4 & 10 \\
\hline 6 & 251 & $\begin{array}{l}\text { Collection of perennials, forest fruits and } \\
\text { medicinal plants }\end{array}$ & 15 & 57 & 48 & 0 & 76 & 44 \\
\hline 7 & 290 & $\begin{array}{l}\text { Other forms of hunting, fishing and collect- } \\
\text { ing specimens of animals or plants }\end{array}$ & 0 & 6 & 6 & 3 & 3 & 6 \\
\hline 8 & 403 & Scattered housing & 0 & 3 & 15 & 5 & 12 & 1 \\
\hline 9 & 420 & Waste, sewage & 0 & 3 & 5 & 0 & 3 & 5 \\
\hline 10 & 421 & Waste and municipal sewage & 1 & 16 & 13 & 0 & 4 & 26 \\
\hline 11 & 500 & Transport network & 2 & 20 & 5 & 0 & 4 & 23 \\
\hline 12 & 501 & Paths, hiking trails, bike trails & 7 & 39 & 50 & 0 & 59 & 37 \\
\hline 13 & 502 & Roads, highways & 3 & 20 & 17 & 0 & 13 & 27 \\
\hline 14 & 503 & Railways & 1 & 4 & 8 & 0 & 8 & 5 \\
\hline 15 & 506 & Airfields, helipads & 0 & 0 & 3 & 0 & 1 & 2 \\
\hline 16 & 507 & Bridges and viaducts & 0 & 4 & 13 & 0 & 10 & 7 \\
\hline 17 & 508 & Tunnels & 1 & 0 & 4 & 3 & 2 & 0 \\
\hline 18 & 509 & Other transport networks & 3 & 9 & 5 & 0 & 5 & 12 \\
\hline 19 & 600 & Sports and recreational infrastructure & 1 & 10 & 11 & 0 & 9 & 13 \\
\hline 20 & 601 & Golf courses & 0 & 0 & 1 & 0 & 0 & 1 \\
\hline 21 & 602 & Ski resorts & 1 & 10 & 13 & 0 & 11 & 13 \\
\hline 22 & 604 & Running and racing tracks & 0 & 0 & 1 & 0 & 0 & 1 \\
\hline 23 & 605 & Equestrian areas & 0 & 1 & 0 & 0 & 0 & 0 \\
\hline 24 & 606 & Leisure parks & 1 & 1 & 0 & 0 & 1 & 1 \\
\hline 25 & 607 & Sports fields & 0 & 1 & 7 & 0 & 6 & 2 \\
\hline 26 & 608 & Campsites and caravan parks & 0 & 3 & 5 & 0 & 3 & 5 \\
\hline 27 & 609 & Other sports and recreational areas & 0 & 6 & 9 & 0 & 7 & 8 \\
\hline 28 & 610 & Educational centres & 1 & 1 & 4 & 4 & 2 & 0 \\
\hline 29 & 620 & Outdoor sports and activities & 4 & 12 & 12 & 0 & 9 & 19 \\
\hline 30 & 621 & Water sports & 5 & 4 & 6 & 0 & 5 & 10 \\
\hline 31 & 622 & Hiking, horse riding and biking tourism & 14 & 58 & 59 & 0 & 78 & 53 \\
\hline 32 & 623 & Off-road and motorcycles & 6 & 19 & 21 & 0 & 2 & 44 \\
\hline 33 & 624 & Mountaineering, rock climbing, caving & 7 & 24 & 18 & 0 & 21 & 28 \\
\hline 34 & 625 & Gliding, paragliding, ballooning & 4 & 14 & 11 & 0 & 5 & 24 \\
\hline 35 & 626 & Skiing, ski touring & 2 & 12 & 10 & 0 & 8 & 16 \\
\hline 37 & 629 & $\begin{array}{l}\text { Other sports and recreational activities in } \\
\text { nature }\end{array}$ & 2 & 9 & 10 & 0 & 7 & 14 \\
\hline 38 & 690 & $\begin{array}{l}\text { Other possible effects of recreational and } \\
\text { sport activities }\end{array}$ & 1 & 3 & 3 & 0 & 5 & 2 \\
\hline 39 & 720 & Trampling; excessive exploration & 7 & 20 & 7 & 0 & 1 & 33 \\
\hline 40 & 740 & Vandalism & 8 & 18 & 11 & 0 & 2 & 35 \\
\hline 41 & 870 & Dams, embankments, use of river banks & 5 & 7 & 9 & 4 & 5 & 12 \\
\hline 42 & 900 & Erosion & 12 & 39 & 18 & 1 & 11 & 57 \\
\hline 43 & 942 & Avalanches and other mass movements & 3 & 6 & 3 & 1 & 9 & 2 \\
\hline 44 & 952 & Eutrophication & 5 & 15 & 13 & 0 & 4 & 29 \\
\hline 45 & 954 & Invasion of alien species & 5 & 39 & 36 & 0 & 9 & 71 \\
\hline
\end{tabular}

In terms of activity effects, almost $20 \%$ of selected activity types showed significant differences. In 8 types of activities: collection of perennials, forest fruits and medicinal plants $(p=0,0481)$; transport network $(p=0,0100)$; paths, hiking trails, bike trails $(p=0,0080)$; other transport networks $(p=0,0248)$; water sports $(\mathrm{p}=0,0284)$; hiking, horse riding and biking tourism $(p=0,0010)$; other sports and recreational activities in nature $(p=0,0107)$; dams, embankments, use of river banks $(p=0,0449)$. Activities inside the Natura 2000 sites more often referred to as negative than in their vicinity. However, tunnels (code 508) were perceived as having a significantly more positive effect inside the Natura 2000 sites than in their vicinity $(p=0,0297)$. 
Table 2 - Number of areas adjacent to Natura 2000 sites where tourism and recreation-related activities were recorded (the Alpine Bioregion) Source: authors' own studies.

\begin{tabular}{|c|c|c|c|c|c|c|c|c|}
\hline \multirow[b]{2}{*}{ No. } & \multirow{2}{*}{$\begin{array}{l}\text { Activity } \\
\text { code }\end{array}$} & \multirow[b]{2}{*}{ Activity type } & \multicolumn{3}{|c|}{ Intensity of activity } & \multicolumn{3}{|c|}{ Effects of activity } \\
\hline & & & $\begin{array}{l}\text { strong } \\
\text { (A) }\end{array}$ & $\begin{array}{l}\text { average } \\
\text { (B) }\end{array}$ & $\begin{array}{l}\text { low } \\
\text { (C) }\end{array}$ & $\begin{array}{l}\text { positive } \\
(+)\end{array}$ & $\begin{array}{l}\text { neutral } \\
(0)\end{array}$ & $\begin{array}{l}\text { negative } \\
(-)\end{array}$ \\
\hline 1 & 220 & Fishing & 5 & 30 & 17 & 1 & 44 & 7 \\
\hline 2 & 230 & Hunting & 39 & 74 & 44 & 4 & 113 & 40 \\
\hline 3 & 240 & Taking and removal animals in general & 1 & 4 & 6 & 1 & 1 & 9 \\
\hline 4 & 241 & $\begin{array}{l}\text { Taking and removal insects, amphibians, or } \\
\text { reptiles }\end{array}$ & 0 & 3 & 11 & 0 & 2 & 12 \\
\hline 5 & 250 & Plant collection in general & 1 & 10 & 3 & 0 & 4 & 10 \\
\hline 6 & 251 & $\begin{array}{l}\text { Collection of perennials, forest fruits and } \\
\text { medicinal plants }\end{array}$ & 15 & 44 & 40 & 1 & 75 & 23 \\
\hline 7 & 290 & $\begin{array}{l}\text { Other forms of hunting, fishing and collect- } \\
\text { ing specimens of animals or plants }\end{array}$ & 1 & 4 & 4 & 0 & 4 & 5 \\
\hline 8 & 403 & Scattered housing & 0 & 7 & 9 & 1 & 15 & 0 \\
\hline 9 & 420 & Waste, sewage & 4 & 12 & 6 & 0 & 4 & 18 \\
\hline 10 & 421 & Waste and municipal sewage & 6 & 34 & 15 & 0 & 7 & 48 \\
\hline 11 & 500 & Transport network & 10 & 17 & 9 & 0 & 16 & 20 \\
\hline 12 & 501 & Paths, hiking trails, bike trails & 1 & 28 & 38 & 0 & 54 & 13 \\
\hline 13 & 502 & Roads, highways & 24 & 63 & 32 & 0 & 42 & 77 \\
\hline 14 & 503 & Railways & 11 & 21 & 15 & 0 & 24 & 23 \\
\hline 15 & 505 & Airports and airport infrastructure & 0 & 3 & 1 & 0 & 1 & 3 \\
\hline 16 & 506 & Airfields, helipads & 0 & 0 & 10 & 0 & 3 & 7 \\
\hline 17 & 507 & Bridges and viaducts & 0 & 9 & 7 & 0 & 8 & 8 \\
\hline 18 & 508 & Tunnels & 1 & 0 & 3 & 0 & 4 & 0 \\
\hline 19 & 509 & Other transport networks & 1 & 5 & 5 & 0 & 8 & 3 \\
\hline 20 & 600 & Sports and recreational infrastructure & 7 & 20 & 12 & 0 & 20 & 19 \\
\hline 21 & 601 & Golf courses & 0 & 2 & 0 & 0 & 2 & 0 \\
\hline 22 & 602 & Ski resorts & 5 & 12 & 6 & 0 & 9 & 14 \\
\hline 23 & 603 & Stadiums & 1 & 1 & 4 & 0 & 4 & 2 \\
\hline 24 & 604 & Running and racing tracks & 1 & 0 & 1 & 0 & 0 & 2 \\
\hline 25 & 605 & Equestrian areas & 1 & 2 & 1 & 0 & 3 & 1 \\
\hline 26 & 606 & Leisure parks & 1 & 0 & 1 & 0 & 0 & 2 \\
\hline 27 & 607 & Sports fields & 1 & 5 & 11 & 0 & 14 & 3 \\
\hline 28 & 608 & Campsites and caravan parks & 2 & 7 & 13 & 0 & 11 & 11 \\
\hline 29 & 609 & Other sports and recreational areas & 3 & 9 & 10 & 0 & 10 & 12 \\
\hline 30 & 610 & Educational centres & 1 & 0 & 7 & 6 & 1 & 1 \\
\hline 31 & 620 & Outdoor sports and activities & 8 & 21 & 9 & 0 & 22 & 16 \\
\hline 32 & 621 & Water sports & 3 & 3 & 6 & 0 & 9 & 3 \\
\hline 33 & 622 & Hiking, horse riding and biking tourism & 9 & 33 & 61 & 0 & 82 & 21 \\
\hline 34 & 623 & Off-road and motorcycles & 7 & 20 & 16 & 0 & 4 & 39 \\
\hline 35 & 624 & Mountaineering, rock climbing, caving & 4 & 7 & 8 & 0 & 10 & 9 \\
\hline 36 & 625 & Gliding, paragliding, ballooning & 5 & 6 & 12 & 0 & 8 & 15 \\
\hline 37 & 626 & Skiing, including off-piste, ski touring & 4 & 9 & 11 & 0 & 12 & 12 \\
\hline 38 & 629 & $\begin{array}{l}\text { Other sports and recreational activities in } \\
\text { nature }\end{array}$ & 3 & 8 & 8 & 0 & 14 & 5 \\
\hline 39 & 690 & $\begin{array}{l}\text { Other possible effects of recreational and } \\
\text { sport activities }\end{array}$ & 1 & 2 & 2 & 0 & 3 & 2 \\
\hline 40 & 720 & Trampling; excessive exploration & 3 & 9 & 2 & 1 & 0 & 13 \\
\hline 41 & 740 & Vandalism & 0 & 15 & 9 & 0 & 3 & 21 \\
\hline 42 & 870 & Dams, embankments, use of river banks & 6 & 10 & 4 & 0 & 4 & 16 \\
\hline 43 & 900 & Erosion & 6 & 24 & 15 & 1 & 8 & 36 \\
\hline 44 & 942 & Avalanches and other mass movements & 0 & 1 & 1 & 0 & 1 & 1 \\
\hline 45 & 952 & Eutrophication & 10 & 17 & 9 & 0 & 2 & 34 \\
\hline 46 & 954 & Invasion of alien species & 22 & 44 & 30 & 0 & 7 & 89 \\
\hline
\end{tabular}

In terms of activity effects, almost $20 \%$ of selected activity types showed significant differences. In the majority of the cases, activities inside the Natura 2000 sites more often referred to as negative than in their vicinity. However, tunnels (code 508) were perceived as having a significantly more positive effect inside the Natura 2000 sites than in their vicinity. 


\section{Discussion}

Of 45 types of activities mentioned inside or in the vicinity of the Natura 2000 sites, only 10 were considered positive in 28 cases of completed SDFs. The most significant types of human activities, related to a broadly understood tourism and recreation, and having a positive effect on the Natura 2000 areas were: the existence of scattered housing -5 cases; construction of dams, shafts and use of river banks -4 cases, and the impact of educational centres located in the Natura 2000 areas - 4 cases. In the adjacent areas to the Natura 2000 sites, positive types of tourism and recreation-related activities were activities of educational facilities -6 cases, and hunting -4 cases.

The results show that the high impact intensity of a given factor may not necessarily be a basis for concern or for the conclusion that it poses a threat to the area. High intensity factors, although often associated with a negative influence on the environment, may not necessarily affect it negatively every time. For instance hunting, which is the most frequently mentioned factor affecting the Natura 2000 areas and the adjacent areas, and the most intensive type of activity A (strong ): in $1 \%$ of cases is it treated as having a positive effect, in $67 \%$ as neutral, and only in $32 \%$ of all areas is it perceived as having a negative effect.

Hunting represents $1.3 \%$ of all 28 cases of positive effects, $18 \%$ of all 565 activities are seen as neutral and $6.1 \%$ of all 804 as having negative effects. In spite of the fact that hunting is mentioned as the most frequent activity and usually with a strong influence on the area, in the light of the data obtained from SDFs it does not pose any threat to the protected Natura 2000 areas.

The comparison between Natura 2000 and adjacent areas shows that generally there are no differences in intensity for the activity types analysed. The significant differences in terms of intensity were noted only for invasive alien species and vandalism. The higher intensity of threats related to invasive alien species inside the Natura 2000 results from the absence of a protective regime that would prevent alien species from growing and spreading, and a higher density of settlements accompanied by green infrastructure outside the Natura 2000 sites. Research indicates that settlements are regarded as the main source of alien species invasions to protected areas (McNeel 2001). However, the reason for higher intensity of vandalism inside the Natura 2000 is less known. There is little evidence that behaviour considered as vandalism happens more often inside the sites than in their vicinity. The difference may be explained by the fact that such behaviour, e.g. picking up flowering plants inside the Natura 2000 sites, are not perceived as vandalism in the adjacent areas.

While no significant differences in the analysis of activity intensity inside the Natura 2002 sites and in the adjacent areas were observed, the discrepancy in the analysis of activity effects was noted. It may be explained in two ways. First, it is assumed that the same intensity of a given factor causes a stronger environmental reaction inside the Natura 2000 sites, e.g. bigger participation of primal and more sensitive ecosystems within the site that in the adjacent site. Second, the discrepancy may be caused by the practice of filling out the SDFs. Instructions related to the assessment of intensity and effects of activities are not entirely objective. Thus, a factor of the same intensity may be assessed differently in terms of its effect.

Both mechanisms are perhaps responsible for indicating negative effects of the same forms of activities more often inside than outside the Natura 2000 sites. The only factor indicated as positive more frequently within the Natura 2000 site than outside it, are tunnels (code 508). This difference stems from the fact that tunnels not only are constructed due to technical requirements of road development, but also to enable animal migration.

The results obtained from this study indicate that broadly understood tourism and recreational activities are an inherent element of human influence on biodiverse areas. Therefore, they should be taken into consideration when managing the Natura 2000 sites and for their adjacent areas.

\section{References}

Dubel, A., M. Jamontt-Skotis, K. Królikowska, J. Stefańska \& A. Banrowska 2010. Skuteczne zarzqdzanie obszarami Natura 2000. Stowarzyszenie Centrum Rozwiązań Systemowych, Wrocław-Kraków: 37-49.

ETC/BD - European Topic Centre on Biological Diversity 2006. The indicative Map of European Biogeographical Regions: Methodology and development. Muséum National d'Histoire Naturelle. Paris.

Freitag, R. \& D. Pyka 2011. Status Quo and Forecasting World and European Tourism. In: Roland, C. \& M. Buck (eds.), Trends and Issues in Global Tourism: 3-14.

Gorczyca, E. \& K. Krzemień 2002. Wplyw ruchu turystycznego na rzeźbe Tatrzańskiego Parku Narodowego. In: Borowiec, W., A. Kotarba, A. Kownacki, Z. Krzan \& Z. Mirek (eds.), Przemiany środowiska prayrodniczego Tatr. Tatrzański Park Narodony, Polskie Towarzystwo Prayjaciót Nauk o Ziemi, Oddqiat Kraków, Kraków - Zakopane: 389 -394 .

Hresko, J. \& G. Bugar 2001. Problems of natural hazard assessment and monitoring in the Tatra Mts. Ekologia-Bratislava 20: 96-100.

Kombol, P. 2000. Rural tourism on the Croatian islands - Sustainable development and regenerative strategies. Periodicum Biologorum 102: 425-431.

Krnacova, Z, K. Pavlickova \& P. Spisiak 2001. The assumptions for the tourism development in rural areas in Slovakia. Ekologia-Bratislava 20 (3): 317-324.

Lidle M. 1997. Recreation ecology. London. 
Łajczak A. 1996. Wpływ narciarstwa i turystyki pieszej na erozję gleby w obszarze podszczytowym Pilska. In: Lajczak, A., S. Michalik \& Z. Witkowski (eds.), Wplyw narciarstwa i turystyki pieszej na prayrode Masywu Pilska. Studia Naturae 41: 131-159.

Makomaska-Juchiewicz, M. \& S. Tworek 2003. Miejsce sieci Natura 2000 w europejskiej ochronie prayrody. In: Makomaska-Juchiewicz, M. \& S. Tworek (eds.), Ekologiczna sié́ Natura 2000, problem çy szansa. Instytut Ochrony Przyrody PAN, Kraków: 9-21.

Maikhuri, R.K., U. Rana, K.S. Rao, S. Nautiyal \& K.G. Saxena 2000. Promoting ecotourism in the buffer zone areas of Nanda Devi Biosphere Reserve: an option to resolve people-policy conflict. International Journal of Sustainable Development and World Ecology 7 (4): 333-342.

McNeel, J.A. 2001. An Introduction to Human Dimensions of Invasive Alien Species. In: McNeel, J.A. (ed.), The Great Reshuffling Human Dimensions of Invasive Alien Species. IUCN. Cambridge: 4-20.

NATURA 2000 Standard Data Form Explanatory Notes 1999. Available at: http://ec.europa.eu/ environment/nature/legislation/habitatsdirective/ docs/standarddataforms/notes_en.pdf (accassed $01 / 03 / 2014)$

Neto, F. 2003. A new approach to sustainable tourism development: Moving beyond environmental protection. Natural Research Forum 27 (3): 212-222.

Reiter, A. 2011. Eco-leadership and Green Lifestyle: Successful Strategy for a Growing Market Segment? In: Roland, C. \& M. Buck (eds.), Trends and Issues in Global Tourism: 93-96.

Sokal, R.R. \& J.R. Rohlf 1995. Biometry: The Principles and Practices of Statistics in Biological Research. Third Edition. New York.

Witkowski, Z. 1996. Narciarstwo i ochrona przyrody na Pilsku: tło i przyczyny konfliktu. In: Łajczak, A., S. Michalik \& Z. Witkowski (eds.), Wplyw narciarstwa $i$ turystyki pieszej na prayrode Masywu Pilska. Studia Naturae 41: 5-12.
Wójcik, B. 2010. Natura 2000 - podstawowe informacje. In: Kamieniecka, J. \& B. Wójcik (eds.), Natura 2000. ABC dla turystyki. Instytut na rzecz Ekorozwoju, Warszawa: 13-14.

\section{Authors}

\section{Szymon Ciapała}

Head of Ecology Faculty; Academy of Physical Education in Kraków. His scientific interests focus on the issues of tourist impact on nature and methods of tree ring dating as assessment of the touristic impact.

\section{Paweł Adamski}

Researcher at the Institute of Nature Conservation PAS. Specializes in the implementation of the population and behavioural ecology into nature conservation practices, also interested in environmental impact of the tourism and recreation.

\section{Adam Mroczka}

Lecturer at the Ecology Faculty, Academy of Physical Education in Cracow. His research interests focus on environmental conditions of tourist movements, the influence of the environment on human health and bioclimatic conditions of human settlements.

\section{Juraj Svajda}

Assistant at Matej Bel University in Banská Bystrica (Slovakia). His research interests focus on Protected Area Management including monitoring of visitors in national parks.

\section{Zbigniew Witkowski}

Head of Department of Environmental Sciences. Author of over 270 publications on nature conservation and tourism, interested in the management of tourism in the context of nature conservation in protected areas. 